\title{
Hubungan Kepercayaan Petani Terhadap Penjualan Bahan Olah Karet Kepada Pedagang Pengumpul di Kabupaten Muaro Jambi Provinsi Jambi
}

\author{
Abu Amar ${ }^{1)}$, Saad Murdy ${ }^{2)}$, Idris Sardi ${ }^{2)}$
}

1) Alumni Jurusan Agribisnis Fakultas Pertanian Universitas Jambi

2) Staf Pengajar Jurusan Agribisnis Fakultas Pertanian Universitas Jambi

Email : Abuamar.d1b011080@gmail.com

\begin{abstract}
Abstrak
Kepercayaan merupakan hubungan antara dua belah pihak atau lebih yang mengandung harapan yang saling menguntungkan satu pihak atau kedua belah pihak melalui interaksi sosial. Kepercayaan pada dasarnya terikat, bukan kepada resiko namun kepada berbagai kemungkinan. Kepercayaan pada penelitian ini terjalin antara petani kepada pedagang pengumpul. Beberapa faktor yang mempengaruhi petani menjual bahan olah karet kepada pedagang pengumpul yaitu pengetahuan petani tentang harga, hutang petani, modal pedagang pengumpul dan hubungan kekeluargaan. Penelitian ini bertujuan untuk mengetahui hubungan kepercayaan petani terhadap penjualan bahan olah karet kepada pedagang pengumpul di Kabupaten Muaro Jambi. Pemilihan lokasi dilakukan secara purposive dengan mempertimbangkan bahwa Kabupaten Muaro Jambi merupakan salah satu sentral produksikaret di Provinsi Jambi namun hanya memilki satu pasar lelang dan sebagian besar petani menjual bahan olah karet kepada pedagang pengumpul. Jenis data dalam penelitian ini meliputi data primer dan data skunder. Data di analisis secara deskriptif melalui Tabel distribusi frekuensi. Uji analisis yang digunakan adalah uji dengan motode ChiSquare $\left(\mathrm{X}^{2}\right)$. Hasil penelitian menunjukkan : 1) Kepercayaan petani yang terdiri dari beberapa faktoryang mempengaruhi seperti pengetahuan petani tentang harga, hutang petani kepada pedagang pengumpul, modal pedagang pengumpul dan hubungan kekerabatan petani kepada pedagang pengumpul dengan kategori kuat sebesar 52,53 persen. 2) Penjualan bahan olah karet kepada pedagang pengumpul kategori tinggi sebesar 54,54 persen. 3) Terdapat hubungan antara kepercayaan petani terhadap penjualan bahan olah karet kepada pedagang pengumpul secara nyata.
\end{abstract}

Kata kunci : Kepercayaan Petani, Penjualan Bahan Olah Karet, Pedagang Pengumpul

\section{Abstract}

Trush is a relationship between two parties or more. By social interaction, trush gives some benefit to each other or party only. Trush is not bounded by the risk but by any probabilities. Trush in this research was defined between farmer and brokers. Some factors which affected farmers to sell their latex to brokers were price, farmer's debt, the broker's capital, and siblings. The research aimed to know the reletionship between farmers trush in selling their latex to brokers. The research was taken place in Muaro Jambi. Muaro Jambi was chosen purposively because it was one of many central latex produktion in Jambi but it had only an auction market. Besides that, most of farmers in Muaro Jambi sold their latex production to brokers. Primary and secondary date were used in this research and descriptively analyzed by frequently table of distribution. Chi-squared test was used to analyze data. The result shower that : 1) Trush affected by some factors such as price, debt, the broker's capital, and siblings among farmers and brokers were strong-categorized $(52,53 \%), 2)$ to sell latex to brokers was high-categorized $(54,54 \%), 3)$ there was a reletionship between farmers and brokers in latex selling.

Keywords: Farmer's trush, sales latex, wholesaler. 


\section{PENDAHULUAN}

Pemasaran merupakan suatu kegiatan usaha yang mengarahkan aliran barang atau jasa dari produsen kepada konsumen atau segala kegiatan yang berhubungan dengan perpindahan hak milik dan fisik barang-barang hasil pertanian dari tangan produsen ke tangan konsumen termasuk kegiatan-kegiatan yang ada didalamnya (The American Marketing Association dalam Swasta, 2007 dan Daniel, 2002). Dalam pemasaran ini, barang mengalir dari produsen sampai ke konsumen akhir yang disertai penambahan guna bentuk melalui proses pengolahan, guna tempat melalui proses pengangkutan dan guna waktu melalui proses penyimpanan. Barang dan jasa disampaikan dari produsen ke konsumen melalui pihak perantara yang saling berhubungan membentuk beberapa tataniaga pemasaran.

Menurut Mubyarto (1989) menyatakan bahwa istilah tataniaga di Indonesia diartikan sama dengan pemasaran atau distribusi yaitu proses pengaliran atau pergerakan barang dari tangan produsen ke tangan konsumen. Tataniaga tidak hanya sekedar menyampaikan barang dari tangan produsen ke tangan konsumen, tetapi dari aspek-aspek yang harus diperhatikan diantaranya adalah lamanya produk sampai ke ketangan konsumen, mampu menyampaikan barang dengan biaya tataniaga semurah mungkin dan juga kepuasan konsumen terhadap barang yang mereka terima, ini dikarenakan produk pertanian bersifat perishable atau tidak tahan lama. Pemasaran bahan olah karet dari petani tidak akan bisa langsung sampai ke pabrik crumb rubber sehingga dilakukan melalui dua saluran pemasaran yaitu lembaga formal (lelang) dan lembaga non formal (non lelang). Lembaga formal (lelang) yaitu pasar lelang dan Koperasi. Lembaga non formal (non lelang) yaitu pedagang pengumpul desa dan pedagang pengumpul luar desa.

Banyaknya lembaga pemasaran yang dilalui petani dalam memasarkan hasil bokar ke pabrik crumb rubber akan menyebabkan besarnya biaya produksi dan biaya pemasaran sehingga akan berpengaruh terhadap harga yang diterima petani. Hal ini mengakibatkan perbedaan harga yang terjadi di setiap saluran pemasaran semakin panjang saluran yang dilalui maka harga akan semakin kecil. Petani akan dirugikan karena akan mendapatkan harga yang semakin murah. Dalam pemasaran bokar di Kabupaten Muaro Jambi kepercayaan petani terhadap pedagang pengumpul masih sangat kuat sehingga petani lebih memilih menjual hasil bahan olah karetnya kepada pedagang pengumpul. Hal ini dikarenakan beberapa faktor penunjang yang membuat petani lebih percaya kepada pedagang pengumpul dari pada langsung menjual ke pasar lelang atau saluran pemasaran lainnya.

Hubungan yang terjadi antara petani dengan pedagang pengumpul tidak hanya terbatas pada transaksi jual beli saja, akan tetapi ada beberapa faktor yang mempengaruhi kepercayaan petani menjual hasil bokarnya kepada pedagang pengumpul diantaranya yaitu pengetahuan petani tentang harga, modal pedagang pengumpul, hutang petani kepada pedagang pengumpul dan adanya hubungan kekerabatan. Berdasarkan survei awal petani juga lebih mempercayai pedagang pengumpul daripada saluran pemasaran lain juga dikarenakan oleh modal yang dimiliki pedagang pengumpul karena semakin besar modal yang dimiliki pedagang pengumpul maka kebanyakan petani lebih percaya dan merasa terlindungi oleh pedagang pengumpul karena apabila petani membutuhkan peminjaman baik dalam bentuk uang ataupun dengan berhutang barang kebutuhan sehari-hari petani akan mendapatkan tanpa syarat dan hanya bermodalkan kepercayaan. Hal ini akan mengakibatkan timbul 
hubungan ketergantungan antara petani kepada pedagang pengumpul sehingga membentuk hubungan patron-client, pedagang pengumpul sebagai patron dan petani sebagai client. Dari hal-hal yang melatar belakangi penulis dalam menyusun, perlu kiranya penulis merumuskan masalah untuk lebih memperjelas maksud dan tujuan penelitian ini. Apakah terdapat hubungan antara kepercayaan petani terhadap penjualan bahan olah karet kepada pedagang pengumpul di Kabupaten Muaro Jambi dan faktor-faktor apa saja yang berhubungan dengan kepercayaan petani terhadap penjualan bahan olah karet kepada pedagang pengumpul. Adapun yang menjadi tujuan dalam penelitian ini adalah Untuk mengetahui apakah terdapat hubungan antara kepercayaan petani terhadap penjualan bahan olah karet kepada pedagang pengumpul di Kabupaten Muaro Jambi dan untuk mengetahui faktor-faktor apa yang berhubungan dengan kepercayaan petani terhadap penjualan bahan olah karet kepada pedagang pengumpul.

\section{METODE PENELITIAN}

Penelitian ini di laksanakan di Kabupaten Muaro Jambi khususnya di tiga Kecamatan dan enam Desa terpilih yaitu Kecamatan Sekernan yaitu Desa Bukit Baling dan Suak Putat, Kecamatan Mestong yaitu Desa Nyogan dan Desa Ibru, Kecamatan Sungai Gelam yaitu Desa Sungai Gelam dan Desa Talang Belido. Pemilihan tempat dipilih secara sengaja (purposive) dengan mempertimbangkan bahwa Kabupaten Muaro Jambi merupakan salah satu sentral perkebunan karet di Provinsi Jambi namun hanya memiliki satu pasar lelang dan sebagian besar penduduknya menggantungkan hidupnya pada perkebunan karet. Objek penelitian ini adalah petani yang mengusahakan usahatani karet yang memilki lahan milik sendiri tetapi menjual kepada pedagang pengumpul. Penelitian ini akan dilaksanakan dari bulan Agustus sampai September 2016. Metode penelitian yang digunakan adalah metode deskriptif dan pengumpulan data, data yang digunakan adalah data primer dan data skunder. Data primer diperoleh dari hasil wawancara langsung dengan responden melalui daftar pertanyaan (kuisioner), dan data sekunder. Penetapan Kecamatan sampel ditentukan secara sengaja (purposive), dengan pertimbangan Kecamatan yang memiliki produksi tertinggi. Terpilihlah Kecamatan Sekernan, Kecamatan Mestong dan Kecamatan Sungai Gelam. Dari masing-masing Kecamatan dipilih 2 Desa yang memiliki produksi tertinggi. Penarikan sample dilakukan dengan cara metode Simple random sampling. Sample yang diambil adalah petani karet yang mengusahatanikan sendiri dan memiliki lahan milik sendiri yaitu sebanyak 99 petani yang terbagi atas enam desa terpilih. Kemudian penarikan sampel dilakukan dengan menanyakan pihak desa ada berapa pedgang pengumpul, menanyakan kepada pedagang pengumpul petani yang memiliki lahan sendiri dan menyadap sendiri.

Untuk mengetahui hubungan kepercayaan petani terhadap penjualan bahan olah karet kepada pedagang pengumpul digunakan statistik non parametrik melalui uji Chisquare $\left(X^{2}\right)$. Menurut Usman (2006), uji chi square kooefisien kontingensi (c) $2 \times 2$ dengan $\mathrm{N}$ ada diantara 20 sampai 40 dapat dihitung dengan ketentuan sebagai berikut. Apabila sel berisi frekuensi $\geq 5$, maka rumus yang digunakan:

$\left(\mathrm{X}^{2}\right)=\frac{n\|a d-b c\|^{2}}{(a+b)(c+d)(a+c)(b+d)}: d b=1$

Adapun Tabelnya adalah sebagai berikut: 
Model Analisis Uji Chi-square dengan kontingensi (C) 2×2

\begin{tabular}{|c|c|c|c|}
\hline \multirow[b]{2}{*}{$\begin{array}{c}\text { Kepercayaan } \\
\text { Petani }\end{array}$} & \multicolumn{2}{|c|}{ 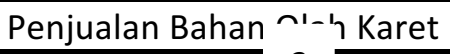 } & \multirow[b]{2}{*}{ Jumlah } \\
\hline & Tinggi & iendah & \\
\hline Kuat & $A$ & B & $A+B$ \\
\hline Lemah & C & $\mathrm{D}$ & $C+D$ \\
\hline Jumlah & $A+C$ & $B+D$ & $\mathrm{~N}$ \\
\hline
\end{tabular}

Dalam pengujiannya nilai $X^{2}$ pada tabel derajat bebas $(\mathrm{db})=1$ pada tingkat kepercayaan 95\% adalah 3,84 dapat dibandingkan $X^{2}$ hitung dengan $X^{2}$ tabel dengan ketentuan sebagai berikut:

Terima $\mathrm{H}_{o}$ tolak $\mathrm{H}_{1}$ jika nilai $X^{2}$ hitung $\leq X^{2}$ tabel

Terima $\mathrm{H}_{1}$ tolak $\mathrm{H}_{0}$ jika nilai $X^{2}$ hitung $\geq X^{2}$ tabel

Dimana :

$\mathrm{H}_{o}$ : Tidak terdapat kolerasi positif antara kepercayaan terhadap penjualan bahan olah karet

$\mathrm{H}_{1}$ : Terdapat kolerasi positif antara kepercayaan terhadap penjualan bahan olah karet Selanjutkan untuk mengukur derajat hubungan antara kedua variable digunakan koefisien kontingensi dengandengan rumus sebagai berikut :

$\mathrm{C}=\sqrt{\frac{X^{2}}{X^{2}+N}}$

Selanjutnya untuk mengukur keeratan hubungan digunakan

Dimana :

$x^{2}=x^{2}$ hitung

$\mathrm{N}=$ Jumlah Sampel

$\mathrm{C}=$ Koefesien Kontingensi, nilai terletak antara 0 sampai 0,707

Formulasi:

$r=\frac{\text { Chit }}{\text { Cmaks }}$ Cmaks $=\sqrt{\frac{m-1}{m}}=\sqrt{\frac{1}{2}}=0,707$

$r=\frac{\sqrt{\frac{x^{2}}{x^{2}+N}}}{\sqrt{\frac{m-1}{m}}}$

Keterangan :

$r=$ koefisien keeratan hubungan

$x^{2}=$ Nilai uji Chi-Square

$\mathrm{N}=$ jumlah sampel

$\mathrm{m}=$ jumlah kolom/ baris yang paling besar

dengan kategori:

Hubungan digolongkan lemah apabila nilai terletak antara 0-0,353

Hubungan digolongkan kuat apabila nilai terletak antara 0,353-0,707

Selanjutnya untuk melihat adanya hubungan secara nyata maka digunakan formulasi yakni: 


$$
t_{\text {hit }}=\sqrt{\frac{N-2}{1-(r)^{2}}}
$$

Dimana :

$\mathrm{H}_{o} ; \mathrm{r}=0$

$\mathrm{H}_{1} ; \mathrm{r} \neq 0$

Jika t hitung $(\leq \mathrm{t}$ tabel $=(\alpha=5 \% \mathrm{db}=\mathrm{N}-2)\}$ Terima $\mathrm{H}_{o}$

Jika t hitung $(\geq \mathrm{t}$ tabel $=(\alpha=5 \% \mathrm{db}=\mathrm{N}-2)\}$ Tolak $\mathrm{H}_{o}$

Dimana :

$\mathrm{H}_{o}=$ Tidak terdapat hubungan yang nyata antara hubungan kepercayaan petani terhadap penjualan bahan olah karet kepada pedagang pengumpul.

$\mathrm{H}_{1}=$ Terdapat hubungan yang nyata antara hubungan kepercayaan petani terhadap penjualan bahan olah karet kepada pedagang pengumpul.

\section{HASIL DAN PEMBAHASAN}

\section{Kepercayaan Petani Kepada Pedagang Pengumpul}

Menurut Lawang (2004) kepercayaan merupakan hubungan antara dua belah pihak atau lebih yang mengandung harapan yang saling menguntungkan satu pihak atau kedua belah pihak melalui interaksi sosial. Kepercayaan disini terjalin antara petani kepada pedagang pengumpul. Untuk lebih jelas dapat dilihat pada Tabel 1.

Tabel 1. Distribusi Frekuensi Skor Petani Sampel berdasarkan Kepercayaan di Daerah Penelitian Tahun 2016

\begin{tabular}{|c|c|c|}
\hline Kepercayaan & Frekuensi & Persentase(\%) \\
\hline Kuat & 52 & 52,53 \\
\hline Lemah & 47 & 47,47 \\
\hline Jumlah & 99 & 100 \\
\hline
\end{tabular}

pedagang pengumpul di daerah penelitian kuat sebesar 52,53\% petani percaya kepada pedagang pengumpul. Kepercayaan ini dilihat dari pengetahuan petani tentang harga, modal yang dimiliki pedagang pengumpul, hutang yang dimiliki petani kepada pedagang pengumpul dan hubungan petani kepada pedagang pengumpul (hubungan kekerabatan, teman ataupun fatner kerja) antara petani dengan pedagang pengumpul.

Sebanyak $89.90 \%$ petani di tempat penelitian mengetahui harga yang dibeli pedagang pengumpul. Tetapi banyak petani yang tidak mengetahui harga yang dibeli pabrik crumb rubber yaitu sebanyak $87.88 \%$ petani. Berapa pun harga yang diberikan pedagang pengumpul petani akan menerima saja karena harga ditentukan oleh pedagang pengumpul dan petani tidak mengetahui harga yang dibeli pabrik crumb rubber. Petani merasa dirugikan karena harga yang ditawarkan dipedagang pengumpul yang jauh dibandingkan harga pabrik. Hal ini dilihat dari persentase jumlah petani yang merasa dirugikan karena harga yang dientukan sepihak oleh pedagang pengumpul. Sebanyak $68.38 \%$ petani merasa dirugikan karena harga yang ditawarkan pedagang pengumpul jauh dibandingkan harga yang ditawarkan pabrik crumb rubber. Tetapi 
petani tidak bisa berbuat apa-apa karena petani tidak bisa menyampaikan langsung bokar nya ke pabrik crumb rubber dan tidak banyak petani yang menganggap hal ini biasa, karena biaya transportasi dan saluran pemasaran yang panjang sehingga bisa sampaike pabrik crumb rubber, hal ini sejalan dengan penelitian Arfandi (2007) bahwa petani yang mengetahui harga bokar ditingkat pedagang sebesar $60 \%$, petani yang tidak mengetahui harga karet ditingkat pabrik sebesar $75 \%$.

Para pedagang selalu menjadi tumpuan harapan apabila petani mengalami kesulitan keuangan, karena tidak ada satupun lembaga keuangan pedesaan yang mampu menandingi efektifitas pedagang perantara dalam menanggulangi kesulitan petani dan sebagai imbalannya petani akan selalu setia memasok kebutuhan karet pedagang walaupun seringkali terdapat pilihan harga yang lebih baik (Napitupulu,2011). Sejalan dengan itu ada sebanyak $71.72 \%$ petani memiliki hutang kepada pedagang pengumpul. Hutang petani kepada pedagang pengumpul berakibat petani akan terikat kepada pedagang pengumpul dan akan terus menjual kepada pedagang pengumpul. Hutang petani kepada pedagang pengumpul bisa dalam bentuk uang tunai dan bisa dalam bentuk barang-barang kehidupan sehari-hari. Pinjaman hutang baik berupa hutang uang dan barang-barang kehidupan sehari-hari akan membuat petani terikat kepada pedagang pengumpul dan akan terus menjual bokar miliknya kepada pedagang pengumpul.

Berdasarkan survei awal bahwa petani lebih memilih menjual bahan olah karet miliknya kepada pedagang pengumpul yang memiliki modal yang cukup besar baik modal tetap ataupun modal tidak tetap. Menurut Soekartawi (2002), modal dalam usaha tani dapat diklasifikasikan sebagai bentuk kekayaan, baik berupa uang maupun barang yang di gunakan untuk menghasilkan sesuatu baik secara langsung maupun tidak langsung dalam proses produksi. Berdasarkan penelitianada sebanyak $70.71 \%$ pedagang pengumpul yang memiliki toko dan menjual barang-barang kebutuhan sehari-hari. Dengan tersedianya toko yang dimiliki pedagang pengumpul disaat petani membutuhkan barang-barang yang diperlukan petani pedagang pengumpul menyediakannya dan barang-barang itu bisa dibeli secara langsung ataupun di hutangkan yang nanti nya akan dibayar pada saat petani menjual bokar ke pada pedagang pengumpul. Selanjutnya petani juga mengharapkan agar pembayaran bokar yang dijual petani langsung dibayaratau tunai dimuka. Sebanyak $88.89 \%$ petani langsung membayar tunai dimuka pada saat petani menjual bahan olah karet miliknya. Dengan demikian petani tidak khawatir, disaat petani membutuhkan uang dan memiliki bokar untuk dijual petani tidak merasa takut apabila akan mendapatkan penundaan penerimaan uang karena pedagang pengumpul langsung membayar hasil bokar tunai langsung dimuka. Sebanyak $92.93 \%$ pedagang pengumpul memberikan tunjangan hari raya kepada petani yang menjual bokar kepada pedagang pengumpul. Pemberian tunjangan hari raya ini membuat petani menganggap bahwa pedagang pengumpul merupakan orang yang baik hati sehingga petani akan terus menjual bahan olah karet miliknya kepada pedagang pengumpul.

MenurutDamsar (2013) kepercayaan muncul dari hubungan yang diperoleh berdasarkan atas ciri-ciri yang melekat pada pribadi seperti latar belakang kekerabatan, etnis, dan keturunan yang dimiliki. Petani akan memilih menjual kepada pedagang pengumpul yang memiliki hubungan keluarga, hubungan teman dan hubungan fatner kerja atau sudah turun temurun menjual kepada pedagang pengumpul. Petani yang memiliki hubungan keluarga kepada pedagang pengumpul sebesar $32.32 \%$. Petani yang mengatakan bahwa pedagang pengumpul merupakan teman atau kerabat dekat sebanyak $39.40 \%$ petani. Petani yang mimiliki hubungan fatner kerja atau sudah turun temurun menjual bokar kepada pedagang pengumpul sebanyak $31.31 \%$ petani. Petani 
yang memilki hubungan keluarga, teman dan fatner kerja akan menumbuhkan rasa percaya yang tinggi akan pedagang pengumpul. Sejalan dengan penelitian Hasibuan (2015) sebanyak 16 petani sampel menjual kepada pasar non lelang atau pedagang pengumpul karena hubungan keluarga dan sebanyak23 petani sampel menjual kepada pasar non lelang karena teman.

Penjualan Bahan Olah Karet Kepada Pedagang Pengumpul

Menurut Swastha (2008) faktor yang mempengaruhi penjualan adalah kualitas produk, selera konsumen, dan persaingan harga. Penjualan bahan olah karet di penelitian ini yaitu penjualan bahan olah karet yang dipilih petani terus menerus dalam menjual bahan olah karet kepada pedagang pengumpul. Pedagang pengumpul yang ada di daerah penelitian berjumlah 39 pedagang pengumpul yang terpisah di setiap desa di tiga kecamatan yang ada di kabupaten Muaro Jambi. Untuk lebih jelas dapat dilihat pada Tabel 2.

Tabel 2. Distribusi Frekuensi Skor Penjualan Bahan Olah Karet Petani Sampel kepada Pedagang Pengumpul di Daerah Penelitian Tahun 2016

\begin{tabular}{lcc}
\hline Penjualan Bokar & Frekuensi & Persentase(\%) \\
\hline Tinggi & 54 & 54,54 \\
Rendah & 45 & 45,46 \\
\hline Jumlah & 99 & 100 \\
\hline
\end{tabular}

Berdasarkan Tabel 2 dapat dilihat bahwa skor penjualan terlihat tinggi dengan frekuensi sebanyak 54 dan presentase sebesar $54,54 \%$. Penjualan bahan olah karet kepada pedagang pengumpul ini dilihat dari jumlah skor tertinggi kuisioner pada saat penelitian mengapa petani lebih memilih menjual kepada pedagang pengumpul dari pada saluran pemasaran lainnya. Skor penjualan bahan olah karet kepada pedagang pengumpul dilihat dari beberapa faktor yang membuat petani menjual bokar kepada pedagang pengumpul. Beberapa faktor ini yaitu waktu penjualan bokar, syarat akan bokar yang dibeli pedagang pengumpul dan besar kecilnya susutan yang diberi pedagang pengumpul, volume bokar yang dapat dijual dan waktu penjualan bokar kepada pedagang pengumpul.

Sebanyak $81.82 \%$ petani menjual bahan olah karet miliknya kepada pedagang pengumpul karena susutan atau basi karet yang kecil. Petani akan menjual bokar yang dimiliki kepada pedagang pengumpul yang memberi susutan kecil dibandingkan pedagang pengumpul yang memberikan susutan tidak sesuai dengan seharusnya. Agar petani tidak dirugikan atas timbangan bokar yang diterima petani sehingga menambah hasil pendapatan petani.

Sebanyak $81.682 \%$ petani mengantar hasil bokar yang akan dijual langsung kepada pedagang pengumpul. Sebanyak $18.18 \%$ petani tidak mengantar atau dijemput secara langsung oleh pedagang pengumpul dikebun atau di depan rumah petani menggunakan mobil pedagang pengumpul. Sebagian besar petani menjual kepada pedagang pengumpul yang tidak jauh dari kebun atau rumah petani sehingga petani tidak keberatan mengantar secara langsung kepada pedagang pengumpul karena petani juga mempertimbangkan biaya yang akan dibayar petani untuk potongan penjemputan..

Petani menjual bahan olah karet miliknya kepada pedagang pengumpul karena pedagang pengumpul tidak memilih membeli bahan olah karet petani. Ada sebanyak $52.53 \%$ petani menjual bahan olah karet yang tidak bersih atau masih menggunakan campuran kulit kayu batang karet. Petani memilih menjual bokar miliknya kepada pedagang pengumpul karena pedagang pengumpul tidak memilih membeli bokar. 
Pedagang pengumpul tetap mau membeli bokar yang tergolong kotor namun memurahkan harga dari bokar yang dibelinya.

Petani juga memilih melakukan penjualan bahan olah karet kepada pedagang pengumpul karena tidak menentukan berpa volume bokar yang boleh dijual. Sebanyak 98.98\% petani menjual bokar kepada pedagang pengumpul karena pedagang pengumpul tidak menentukan berpa volume bokar yang boleh dijual. Petani boleh menjual bokar kepada pedagang pengump ' alaupun tidak banyak bokar yang dimiliki petani. Petani pun boleh menjual bokar c ${ }^{7} \mathrm{n}$ bentuk apapun. Petani dapat menjual dlam bentuk slep tebal ataupun dalam bentuk lump.

Selanjutnya petani memilih menjual kepada pedagang pengumpul karena petani bebas menjual kapan pun petani memiliki bokar dan siap dijualkarena pedagang pengumpul tidak menentuakan waktu petani boleh menjual bokar miliknya. Dapat dilihat bahwa sebanyak $70.71 \%$ petani menjual bahan olah karet kepada pedagang pengumpul karena tidak ditentukan waktu petani dapat menjual bokar kepada pedagang pengumpul. Disaat petani membutuhkan uang dan petani memiliki bokar petani dapat langsung menjual bokarnya tanpa menunggu waktu yang ditentukan. Sehingga petani tidak harus meminjam atau menunggu jadwal petani boleh menjual bokar miliknya.

Hubungan Kepercayaan Petani Terhadap Penjualan Bahan Olah Karet Kepada Pedagang Pengumpul

Kepercayaan dibutuhkan dalam hal apapun. Kepercayaan dapat tumbuh dalam diri seseorang dan kepercayaan juga dapat hilang akibat berbagai hal. Kepercayaan dapat dilihat daripetani yang memilih melakuakan penjualan bahan olah karet kepada pedagang pengumpul. Untuk melihat apakah kepercayaan petani berhubungan terhadap penjualan bahan olah karet kepada pedagang pengumpul dapat dilihat dari Tabel 3.

Tabel 3. Kontingensi Hubungan Kepercayaan Petani Terhadap Penjualan Bahan Olah Karet Kepada Pedagang Pengumpul di Daerah Penelitian Tahun 2016

\section{Penjualan Bahan Olah Karet Kepada Pedagang}

\begin{tabular}{|c|c|c|c|}
\hline \multirow{2}{*}{ Kepercayaan } & \multicolumn{2}{|c|}{ Pengumpul } & \multirow{2}{*}{ Jumlah } \\
\hline & Tinggi & Rendah & \\
\hline Tinggi & 34 & 18 & 52 \\
\hline Rendah & 20 & 27 & 47 \\
\hline Jumlah & 54 & 45 & 99 \\
\hline
\end{tabular}

Berdasarkan Tabel 17 memperlihatkan bahwa kepercayaan tinggi maka penjualan bahan olah karet kepada pedagang pengumpul tinggi pula. Kepercayaan yang dimiliki masyarakat di daerah penenlitian tergolong tinggi terhadap penjualan bahan olah karet kepada pedagang pengumpul yaitu sebanyak $34 \%$, kepercayaan terhadap penjualan bahan olah karet kepada pedagang pengumpultergolong rendah yaitu sebesar $27 \%$. Sedangkan kepercayaan dikategorikan tinggi namun penjualan bahan olah karet kepada pedagang pengumpulrendah sebanyak $18 \%$, dan kepercayaan dikategorikan rendah sedangkan penjualan bahan olah karet kepada pedagang pengumpul tinggi sebanyak 20\%. Dapat disimpulkan bahwa semakin tinggi kepercayaan petani terhadap pedagang pengumpul maka semakin tinggi pula penjualan bahan olah karet kepada pedagang pengumpul berdasarkan dengan koofisien kontingensi Chit $=0,990$ yang artinya derajat hubungan kepercayaan petani terhadap penjualan bahan olah karet kepada pedagang pengumpul tergolong kuat karena $C$ hit $=0,990$ dan $C$ max $=0,707$. Sedangkan besarnya keeratan hubungan kepercayaan petani terhadap penjualan bahan olah karet 
kepada pedagang pengumpul sebesar $r=1,400$. Hal ini berati derajat keeratan hubungan antara kepercayaan petani terhadap penjualan bahan olah karet kepada pedagang pengumpul berpengaruh secara nyata.

Berdasarkan hasil uji statistik non parametrik dengan menggunakan uji Chi-Square di peroleh nilai $x^{2}=5,190>x^{2} \operatorname{tab}(\alpha=5 \% \mathrm{db}=1)=3,84$ maka keputusan tolak $\mathrm{H}_{0}$ (terima $H_{1}$ ) yang artinya terdapat hubungan antara kepercayaan petani terhadap penjualan bahan olah karet kepada pedagang pengumpulsecara nyata. Hubungan yang terlihat secara nyata yang dapat dilihat di daerah penelitian antara petani terhadappedagang pengumpul yaitu walaupun petani diberi harga secara sepihak oleh pedagang pengumpul namun petani tetap saja menerima dan mau menjual bahan olah karet miliknya kepada pedagang pengumpul. Hal ini diharapkan petani bahwa rasa percayanya kepada pedagang pengumpul dengan harapan adanya timbal balik diantara petani dan pedagang pengumpul.

Selanjutnya $t_{\text {hit }}=14,071>$ dari $t_{\text {table }}((\geq \mathrm{t}$ Tabel $=(\propto=5 \% \mathrm{db}=97)=1,9958))$ maka tolak Ho terima $\mathrm{H}_{1}$ artinya terdapat hubungan yang nyata antara kepercayaan petani terhadap pengolahan bahan olah karet kepada pedagang pengumpul. Kepercayaan petani terhadap pedagang pengumpul merupakan hal terpenting yang harus di buat pedagang pengumpul agar petani terus menjual bahan olah karet kepada pedagang pengumpul. Semakin tinggi kepercayaan petani kepada pedagang pengumpul maka petani akan tetap bergantung dan akan terus menjual bahan olah karet miliknya kepada pedagang pengumpul tanpa ada paksaan dari pihak lain. Sejalan dengan penelitian Susanti (2001) diketahui bahwa sebagian besar populasi sampel sebanyak $60 \%$ dari total populasi memiliki tingkat kepercayaan yang kuat terhadap lembaga pemasarannya, artinya pada umumnya kepercayaan petani terhadap lembaga pemasaran mampu mempengaruhi petani dalam menjual hasil bokar miliknya.

\section{KESIMPULAN}

Berdasarkan hasil penelitian menunjukkan bahwa hubungan kepercayaan petani terhadap penjualan bahan olah karet kepada pedagang pengumpul di Kabupaten Muaro Jambi terdapat hubungan yang nyata, hasil dari hubungan kepercayaan ini dilihat dari kepercayaan petani kategori kuat sebesar 52,53 persen dan penjualan bahan olah karet dikategorikan tinggi sebesar 54,54 persen. Dimana kepercayaan dikategorikan kuat yang dilihat dari beberapa faktor yang mempengaruhi yaitu pengetahuan petani tentang harga, hutang petani kepada pedagang pengumpul, modal yang dimilki pedagang pengumpul dan hubungan kekerabatan. Sedangkan penjualan bahan olah karet diukur dari beberapa faktor yang mempengaruhi petani memilih menjual kepada pedagang pengumpul yaitu mekanisme pemasaran, susutan bokar (basi), bersihnya bokar dan waktu penjualan. Dari hasil pengukuran maka semakin kuat kepercayaan petani terhadap pedagang pengumpul semakin tinggi pula petani akan terus menjual bahan olah karet kepada pedagang pengumpul. 


\section{UCAPAN TERIMAKASIH}

Ucapan terima disampaikan pada Dekan Fakultas dan Ketua Jurusan Agribisnis Fakultas Pertanian Universitas Jambi. Ucal terima kasih tidak lupa pula saya ucapkan kepada Bapak Kepala Desa, Sekretaris De؛ 9 rta aparatur desa yang ada di Kecamatan Sekernan, Mestong dan Sungai Gelam yang sudah menerima dan membantu memperlancar penelitian ini.

\section{DAFTAR PUSTAKA}

Badan Pusat Statistik. 2015. Jambi Dalam Angka. BPS Provinsi Jambi. Jambi.

Damsar. 2009. Pengantar Sosiologi Ekonomi. Kencana. Jakarta.

Daniel, M. 2002. Pengantar Ekonomi Pertanian. Bumi Aksara . Jakarta.

Dinas Perkebunan Jambi. 2014. Statistika Perkebunan Provinsi Jambi. Dinas Provinsi Jambi. Jambi.

Giddens, A. 2005. Konsekuensi-Konsekuensi Modernitas.Kreasi Wacana. Yogyakarta.

Hasibuan, U.RB. 2015. Faktor-Faktor yang Mempengaruhi Petani Karet Dalam Menjual Karet ke Pasar Lelang dan Non Pasar Lelang di Desa Muhajirin Kecamatan Jambi Luar Kota Kabupaten Muaro Jambi. Jurnal Unja. Universitas Jambi. Jambi.

Lawang. R M Z .2004. Kapital Sosial dalam perspektif sosiologik.FISIS UI Press. Jakarta Mubyarto, 1991. Pengantar Ekonomi Pertanian. LP3ES. Jakarta.

Riduwan. 2009. Rumus dan Data dalam Aplikasi Statistika Untuk Penelitian. Alfabeta. Bandung.

Susanti. 2001. Beberapa Faktor Yang Mempengaruhi prilaku Petani Dalam Penjualan Tandan Buah Segar (TBS) Kelapa Sawit Pada Perkebunan Plasma Pola Pir Trans Di Sungai Bahar. Jurnal Unja. Universitas Jambi. Jambi.

Swastha, B. 2008. Azas-Azaz Marketing. Liberty Yogyakarta Yogyakarta. 